\title{
THE FIRST APPEARANCES OF KAMARES WARE IN THE LEVANT
}

By Robert S. Merrillees

Though well known and often cited, the first occurrences of pottery exports from Minoan Crete to the Bronze Age Levant have never been systematically studied, and their contribution to our understanding of trade relations, history and the relative and absolute chronologies of the eastern Mediterranean region has largely been taken for granted. An excellent illustration of this state of affairs, and the most recent survey of the evidence, is provided by H.-G. BuchHOLZ in his major monograph on Ugarit, Zypern und Ägäis. Kulturbeziehungen im zweiten Jahrtausend vor Chr., published in Münster in 1999, 390 ff. The present work sets out to bring together all of the relevant material which is scattered in numerous publications, museums and depots, and to analyse its contexts with a view to determining synchronisms and dating horizons and drawing some general historical conclusions. It has involved as much archival as bibliographical research since the published data are often incomplete, if not inconsistent, and not all the vases have been sighted as the whereabouts of some are unknown and others have simply disappeared. This synthesis cannot unfortunately be exhaustive since certain problems of definition, location and interpretation remain unresolved and new findings are continuously being made. Particularly vexing for the non-specialist are the competing, even conflicting terminologies for the classification of Middle Minoan pottery. Nevertheless, with the accumulation of fresh evidence and insights, a more coherent and uniform chronological picture has begun to emerge which enables some deductions to be reasonably made about the absolute dating of the Middle Bronze Age in Crete.

If we move eastwards from Crete and the Aegean, along the route most probably taken by the sea-going vessels at the start of the second millennium B.C., we encounter, appropriately enough, on the north coast of Cyprus, the earliest Minoan vase so far discovered in the Levant. It is a bridge-spouted jar from Lapithos Vrysi tou Barba Tomb 806A No. 16 (BuchHolz 1999, 390 n. 1460, with bibliography), classified by Pendlebury as "certainly MMIA (i.e. Knossian fabric contemporary with the end of EM III elsewhere)" (GRACE 1940, 27). It has been attributed by Buchholz and Karageorghis to MM I
(BuchHolz and Karageorghis 1973, 150 No. 1572), by Cadogan to EM III or MM IA (CADOGAN 1983, 513) and by Warren and Hankey to "EM III/early MM IA" (WARren and HANkEY 1989, 115). It has a smoothed matt buff exterior surface, with matt black, black-brown and brown painted decoration outside and inside the rim. Height to rim: $14.9 \mathrm{~cm}$. Diameter of rim $15.0 \mathrm{~cm}$. It has been mended and is almost complete, lacking some sherds which have been filled in with plaster. Though customarily dated to EC IIIB (Åström 1979, 56 ff.; CAdogan 1983, 513), I have argued, on the evidence of the pottery types associated with the Cretan import, that it was deposited in MC I (Merrillees 1979, 21 ff.).

There has been no dispute over the dating in Cyprus of the Kamares Ware cup found in Karmi Palealona Tomb 11B No. 6 (BuchHolz 1999, 390 n. 1462, with bibliography), but how to interpret its relative chronology in Crete is another matter. In his 1983 paper, Cadogan assigns it to "MM IB(-IIA)" (CAdOGAN 1983, 514), while Warren and Hankey place it in "MM IB/MM IIA" (WARREN and HANKEY $1989,115)$. I presume these ascriptions to mean that the cup belongs to the transition between MM IB and MM IIA (cf. MAnning 1995, 109 n. 70). In Cypriote terms the deposit belongs to MC I, late rather than early (cf. MANNING 1995, 108 f.).

Proceeding to the Syrian coast, we start with the first landfall from Cyprus, at Ras Shamra, ancient Ugarit. As Cadogan, Caubet and Matoïan have remarked (CADOGAN 1983, 514 n. 108; CAUBeT and MATOÏAN 1995, $103 \mathrm{f}$.), it is far from clear how many Middle Minoan vases were recovered by Schaeffer at Ras Shamra.

At least five authenticated examples of MM II ware have been recorded at this site. Of the first, which was discovered during the second campaign of excavations in 1930, Schaeffer writes that "dans le mobilier d'une tombe de notre deuxième niveau, découverte pendant la deuxième campagne, se trouvait une tasse en terre cuite mince comme une coquille d'oeuf, certainement importée de Crète. Mais le temps avait rongé le décor polychrome et diminué la valeur démonstrative de la pièce" (SCHAEFFER 1939, 22; cf. SCHAEFFER 1939b, 12, said to have been uncovered during the third season; CourTOIS 
1979 col. 1204). For this reason, presumably, the vase was never illustrated. Elsewhere he states that "dans plusieurs tombes de notre deuxième niveau, et aussi parmi les ruines des habitations, nous avons recueilli des tessons de vases de Kamarès ainsi qu'une tasse entière à la paroi mince comme une coquille d'oeuf, peintes de spirales et de motifs floraux en rouge et blanc sur un fond brun foncé à reflet métallique" (Schaeffer 1939, 54). He then goes on to say that one of these cups was part of the furnishings of a tomb in the large necropolis immediately to the east of the Temple of Baal but does not specify that it is the whole cup whose fabric and decoration he describes. Saltz has equated an "almost intact" MM IIA cup from Ras Shamra in the Louvre (AO 13149) with the specimen recorded by Schaeffer (SAltz 1977, 55) and drawn attention to the confusion over its identification (SALTZ 1977, 55 n. 3), which has been perpetuated by Buchholz who gives it the wrong bibliographical reference (BUCHHOLZ 1999, 392 n. 1468). There are nevertheless discrepancies between the cup in the Louvre and Schaeffer's descriptions, which make certainty about its identification impossible.

The vase (Pl. 1a, Fig. 1) consists of a hemispherical body with out-turned, flaring circular rim, almost carinated; broad low base ring with a central depression appearing inside as a roughly circular depression with a central omphalos; a strap handle rising from the rim to below mid-body. It is made of an extremely hard, thin fabric fired buff-brown on the outer face; traces of a black slip inside and out with a matt remaining finish and white painted decoration. The surfaces inside and out are extremely weathered and the decoration has vanished except on the back of the handle which has white lines across it arranged in narrow angles. Cadogan thought he saw traces of orange painted decoration when he examined the cup in the Louvre many years ago but could scarcely make out any additional designs except lining around the edges of the rim and the base. Height to rim: $6.1 \mathrm{~cm}$. Diameter of rim: approx. $12.1 \mathrm{~cm}$. The cup has been mended and restored, and is incomplete. It is very hard to tell where the sherds end and the coloured plaster takes over, and some of the sherds appear to have been partially overpainted during the restoration. The cup had been crudely made. It is not known whether the vase was found intact but subsequently broken and pieces lost or found broken but mostly complete. If it was the decorated specimen mentioned by SCHAEFFER $(1939,54)$ - and there is no other example extant which matches his description of the painted outline - then the surface must have further deteriorated since its exposure. It is not recorded by CAUbet and MATOİAN (1995, 103 f.).

In any case an evidently MM IIA cup, most likely AO 13149, is said to have been found in 1930 in conjunction with a tall jar without handles (SCHAEFFER 1939, 54, fig. 42) and black or red burnished juglets like the one illustrated in Schaeffer 1939, 53, fig. 41 (cf. SALTz 1977, 55 n. 5). What is troubling about the attribution of the Minoan vase to one of the open inhumations in the second level at Ras Shamra is the fact that in his preliminary reports on the second and third seasons of excavations Schaeffer makes no mention of an import from Crete (SCHAEFFER 1931, 53, fig. 41, 54; SCHAEFFER 1932, 14 ff.) and there is no sign of the vase in the photograph of the funerary deposit in situ (Schaeffer 1939, 54, fig. 42). While

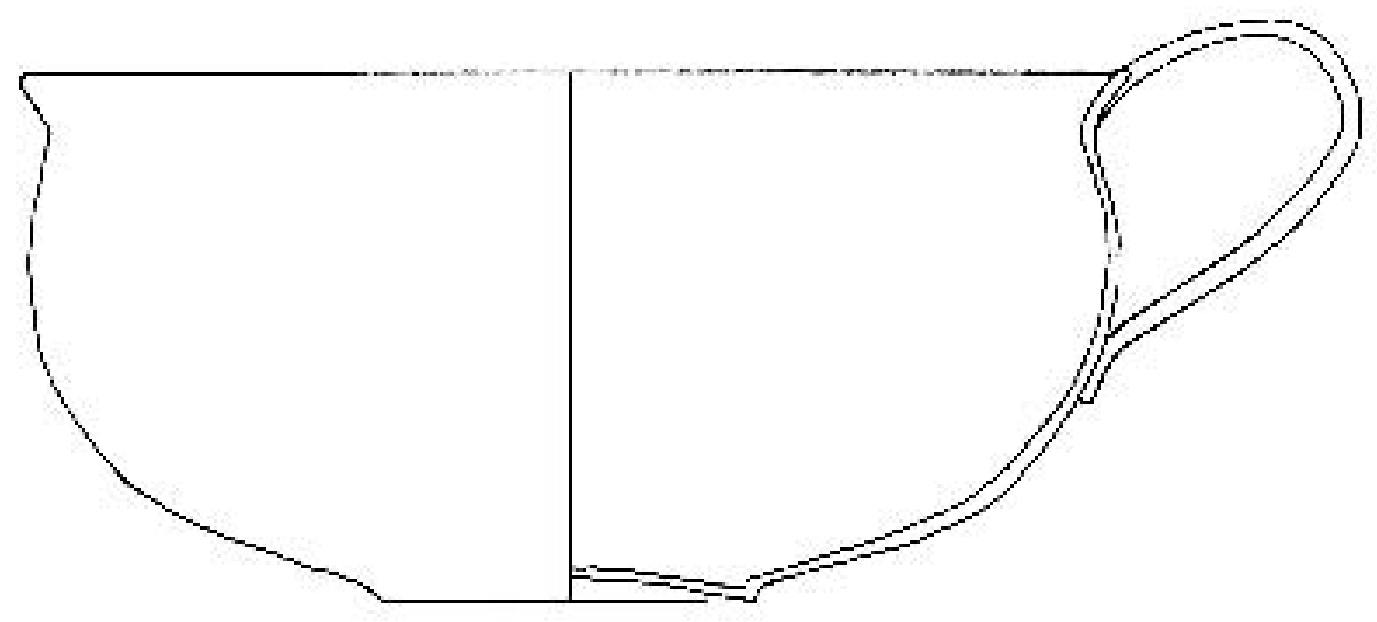

Fig. 1 MM IIA cup. Ras Shamra. Louvre AO 13149 

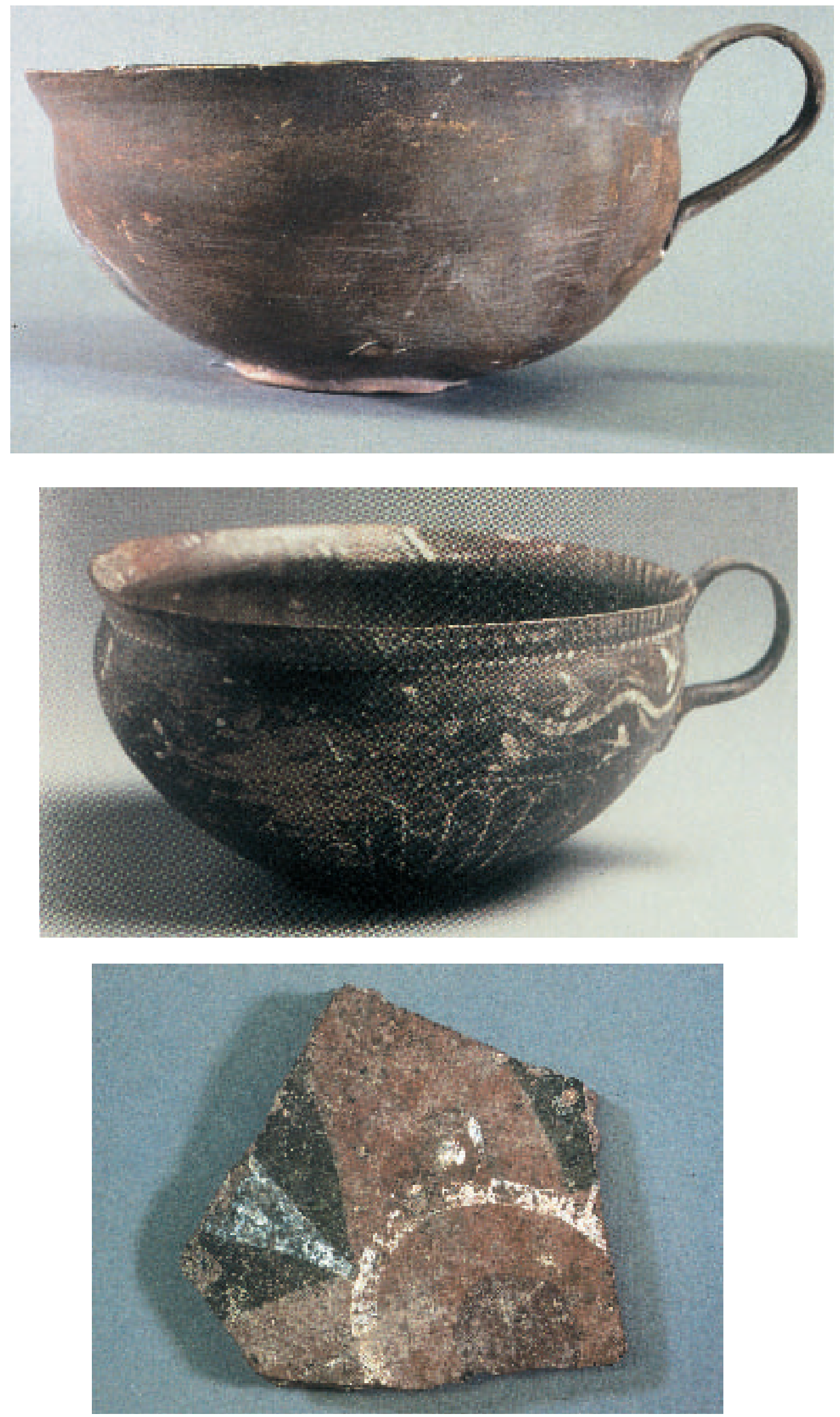

Plate 1 a) MM IIA cup. Ras Shamra. Louvre AO 13149; b) MM IIA cup. Ras Shamra. Louvre AO 20365; c) MM IIB jar sherd. Ras Shamra R.S. 62. Louvre 
Saltz has no hesitation in dating the local juglet type to MB IIA (SALTZ 1977, 55), an attribution confirmed to me by Professor William Dever, the uncertainties about the identification of the piece and its context limit the weight of its chronological evidence.

The specimen recovered from the site in 1936 was the rim sherd of a MM IIA cup which came from an ossuary under the floor of the chamber in Tomb XXXVI (SCHAEFFer 1936, 77 n. 3; SChaefFer 1939b, pl. IV, fig. 1, 12; Pendlebury 1939, 145; Saltz 1977, 53 f.; SCHAEFFER 1978, 375 n. 5, with bibliography; Courtols 1979, col. 1204; BuchHolz 1999, 390 n.1464, with bibliography). MacGillivray would assign it to MM IIB (MaCGillivray 1998, 106). In Cadogan's notes it has been given the Inventory Number 8444 , but the only published reference I have been able to find to the Inventory Numbers of the fragments (sic) of Minoan pottery said to have come from the pit in Tomb XXXVI specify "nos. 8.843 et 1.536 " (VAllois and Ferembach 1962, 567). The only sherd which has been published from this deposit and presumably has the Inv. No. 8843 or 8844 , is now in the Louvre (AO 25554) and has been mentioned by CAUbeT and Matoïan (1995, $104 \mathrm{n}$. 31). Buchholz has mistakenly assigned to this sherd the Louvre accession number of AO 13149, as well as separately giving its correct registration number minus the final "4" (BuchHolz 1999, 392 n. 1468). It has a hemispherical body with out-turned, flaring rim, almost carinated, and is made of an extremely hard, thin fabric fired buff all through; black slip inside and out, overfired or weathered to grey on one side of the outer surface, matt as preserved; matt white painted decoration inside and out. Diameter of rim: approx. $14.5 \mathrm{~cm}$. The surfaces have been weathered. Schaeffer stated that it was found in the ossuary mixed with skeletal remains and several vases, including two juglets, one painted in red and black on a buff slip, the other with a red polished exterior surface. These he dated to the period of the tomb's first use, belonging to the "deuxième niveau de l'époque de la XIIe dynastie" (SCHAEFFER 1936, 77 n. 3), and placed in the Middle Bronze Age (SCHAEFFER 1939, 60, fig. 48, 54 ff.; SCHAEFFER 1978, 375). Saltz has analysed the contents of the deposit and concluded that the local pottery accompanying the Minoan sherd belonged to MB IIB, though their contemporaneity was open to question (SALTZ 1977, $54 \mathrm{n}$. 5). Her dating was independently confirmed by Courtois (COURTOIS 1979, col. 1204). The chronological value of this association is limited.

The third extant specimen of MM IIA ware

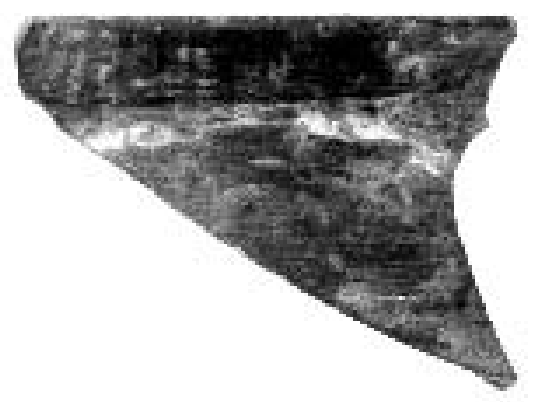

Fig. 2

MM IIA cup rim. Ras Shamra. Ashmolean 1938.581

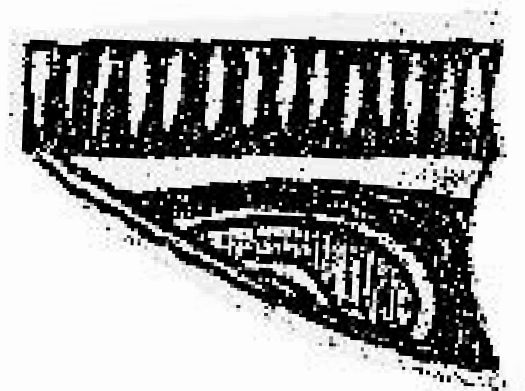

Fig. 3

MM IIA cup rim. Ras Shamra. Ashmolean 1938.581

found at Ras Shamra evidently turned up in 1937 and was presented by Schaeffer to the Ashmolean Museum, Oxford, in 1938 (No. 1938.581) (Report of the Visitors 1938, 13) (Fig. 2). No information about its context accompanied the donation, and though there were no inventory or other numbers than the date written on the sherd, it could have been the second specimen said to have come from the ossuary in Tomb XXXVI (Inv. No. 1536) (see above). It is the rim sherd of a cup with carinated shoulder and everted, straight-sided rim. It was made of extremely hard thin fabric fired buff all through; streaky black and black-brown slip inside and out, burnished to a medium to high remaining finish; fugitive matt white painted decoration on the outside and inside the rim. Though described in the Ashmolean Museum accession register as having "polychrome" decoration (Fig. 3) and by Cadogan as having red painted decoration in addition to white, no other colour than white was evident when I recently examined it in Oxford. In the circumstances it has no chronological value.

The best known and most frequently illustrated MM IIA cup from Ras Shamra was discovered in 1938-1939 (not 1936 - Museen der Stadt Wien 1994, 209) in the dromos of Tomb LXXXVI (Inv. No. 11.573 EC2347) (SchaefFer 1939a, 279f. SALtZ 1977, 54, with bibliography; COURTOIs 1979, col. 
1204; Museen der Stadt Wien 1994, 209 Kat. Nr. 235; Caubet and MatoÏAn 1995, 104 n. 30, n. 31; BuCHHOLZ 1999, 392 n. 1467, with bibliography, n. 1468; Badisches Landesmuseum Karlsruhe 2000, 319 No. 305) (Pl. 1b). It is now in the Louvre (AO 20365) and has a hemispherical body with out-turned flaring rim, almost carinated; broad low base ring with central depression; strap handle rising from rim to midbody. The fabric has been fired brown on the outer face; black slip burnished to a high finish; matt white painted decoration. Height: 6.5 or $8.0 \mathrm{~cm}$. Diameter of rim: 12.0 or $12.5 \mathrm{~cm}$. The outer surface is weathered but the vase is otherwise intact. The cup had been placed on the mouth of an incomplete jar in the dromos of Tomb LXXXVI. The dromos had remained untouched when a well was dug into the funerary chamber during the Late Bronze Age (SchAEFFER 1949, 256). The jar has never been published, and though Schaeffer dated the tomb to "Ugarit Moyen 2", Saltz has concluded that its context does not allow a reliable date to be determined (SAltz 1977, 54 f.).

The last is the unpublished body sherd of a large, closed, hand-made vessel, also from the Southern Acropolis 3.05W $3920-2,40$ (RS. 62), now in the Louvre (Pl. 1c). It is made of a coarse gritty fabric, $0.95 \mathrm{~cm}$. thick, fired brown all through. The exterior surface has been smoothed to an even matt brown finish; black painted decoration, burnished unevenly to a high finish in places, with matt redbrown and white painted decoration. Cadogan has seen a slide of the piece and has no doubt that it came from a large Cretan jar of coarse oatmeal fabric belonging to MM IIB. Its chronological horizon, if any, cannot at present be determined.

Three other sherds from Ras Shamra have Cretan connections, one the spout of a bridge-spouted jar attributed by Schaeffer to MM IIA (SCHAEFFER 1978, 219, fig. 8. 2, 218). Its current whereabouts are unknown. Said to be of buff clay, with a rim diameter of around $10.0 \mathrm{~cm}$., it may have been a local imitation, like the one from Tomb LVII (SCHAEFFER 1939, pl. XIV. centre, 62, fig. 50 [J]; CourTois 1979, col. 1206; MACGillivray 1998, 106). It occurred at Point Topographique 3739 in the Southern Acropolis (R.S. 1961) and cannot be more precisely dated than Schaeffer's attribution of it to the stratum of "Ugarit Moyen 2 (1900-1700)".

Two other fragments from Level II in the socalled Palace Garden were assigned by Kuschke to the Kamares Ware (KuschKe 1962, 269, pl. III. 5, 6, 268). Both were described as being very thin and belonging to "eggshell" ware, with vestiges of black painted decoration on a light ochre slip. No. 5 is portion of a rim of $10 \mathrm{~cm}$. in diameter. Level II, whose pottery could mostly be dated to the Middle Bronze Age (Kuschke 1962, 254), evidently extended well into the Late Bronze Age, as shown, for example, by the sherd of a Cypriote White Slip II milk bowl of Late Cypriote II (Kuschke 1962, 269, pl. III. 1, 268).

The carinated rim sherd of a MM IIA cup was discovered by the Comte du Mesnil du Buisson during his excavations in a cliff at the inland Syrian site of el-Mishrifé, ancient Qatna, near the Orontes. It was made of very fine clay with black surfaces and white and red painted decoration (DU MESNIL DU BUISSON 1926, 324, fig. 41, 325). It was first recognised by C.F.A. Schaeffer, who unhesitatingly described it as Kamares ware (SCHAEFFER 1948, fig. 102. right, 117). MacGillivray has assigned it to MM IIB (MACGILlivray 1998, 106). Though no-one, to the best of my knowledge, has recently sighted the sherd, whose whereabouts are currently unknown, Cadogan accepts the attribution (CADOGAN 1983, 514), which has not been disputed by the other experts. No further details of its findspot have ever been published, and though Åström states that it was dated by the excavator "towards 1500 B.C." (Åström 1962, 146), du Mesnil du Buisson did not specify its chronological horizon on stratigraphical grounds, and Åström has confused the $15^{\text {th }}$ century date given by the excavator to another deposit, with the context of the Minoan sherd. Ward followed Åström's mistake but quoted Parr to the effect that the area of the glacis wall in which the fragment turned up could not be dated with precision at that time (WARD 1971, 78 n. 318). The chronological significance of this find is therefore nil.

It is difficult to know how many Minoan vases have turned up at Byblos on the Phoenician coast. There are certainly two MM IIA bridge-spouted jars, one from Dunand's excavations and the other from a tomb accidentally discovered in 1955. The one from Dunand's excavations at Byblos (No. 2986) (DunAND 1939, pl. CLXXVII. 2986, 193, fig. 178, 191) has been assigned by Cadogan to MM IIA (CADOGAN 1983, 514), though MacGillivray would place it in late MM IIB to early MM IIIA (MacGillivray 1998, 106). It is said to have been deposited in the National Museum of Beirut, but Cadogan evidently did not see it on his visit there in 1966. The Director General of Antiquities in Lebanon has kindly informed me that the re-registration of the reserve collections has now been completed and that the Minoan vases which were 
once stored there are no longer amongst them. The jar came from "levée X", about two metres deep, and was "found at the centre of the rectangle", whatever that means (DunAND 1939, 191; SCHAEFFER 1948, fig. 74, 66).

The outline of the vase published by Dunand was presumably reconstituted from six of the seven sherds described by him as having a black slip decorated with festoons, spirals and swastikas in white. The festoons were also overlaid with small red crosses. Stevenson Smith attempted another reconstruction based on the photograph of the sherds illustrated in Dunand's report, and noted it had a slight difference to the sketch given by Dunand (STEVENSON SMITH 1965, fig. 19, 13). In that illustration six sherds were accompanied by another one having the same inventory No. 2986 but with a brickcoloured surface, enhanced by thick red paint and fugitive white lines. On the basis of Stevenson Smith's reconstruction, the piece in question should be the fragment in the middle of Dunand's photograph (DuNAND 1939, pl. CLXXVII. 2986). All the sherds were said to have been made of the same kind of clay but came from two separate vases. Dunand did not specify the shape of the second specimen, so we do not know if it was an open or closed vessel. It is uncertain on what Ward based his view that it was perhaps part of "a small handled cup" (WARD 1971, 77).

What, however, Cadogan did see in the storeroom of the National Museum in Beirut in 1966 were three pieces of Middle Minoan pottery said to be from Byblos, only one of which has so far been illustrated in print. The first, which is unpublished, is numbered B. 3375 and belongs to the everted rim of a MM IIA hemispherical cup of egg-shell ware (CAdogan 1973, 514 n. 111) (Fig. 4). It has a fine buff clay, a black lustrous wash and thick white and orange-red painted decoration. The diameter of the rim was $13.5 \mathrm{~cm}$.

The second piece, which is also unpublished, was numbered B. 3406 and consisted of the wheel-made base of a MM IIB vase with a fine buff clay, lustrous black wash and thick white painted decoration (CADOGan 1973, 514 nn. 111, 121) (Fig. 5).

The third is a Vapheio cup (Figs. 6, 7) which has been given at least two inventory numbers, B 16728 (CADOGAN 1983, 514 n. 111), and 11/3 N3 XXVIII (CADOGAN notes) or 11/3/13/XXVII (BuchHOLZ 1974, 400; BuchHolz 1999, 392 n. 1470). It so happens that the number " $11 / 3$ N3 XXVII" is visible on the base of the Vapheio cup said to have come from the Kharji cemetery in Beirut (SAIDAH 1993-1994, pl. 17.2a - c, 164, 209 - the number appears in pl. 17. 2c; see below p. 135). This makes the Vapheio cups said to be from Byblos and Beirut one and the same, with incorrect numbers given by both Cadogan and Buchholz. Its real provenance is further complicated by two facts. Firstly, according to Seeden who published Saidah's notes on the Kharji cemetery, the Vapheio cup had no recorded context, excavation number or National Museum registration number (SAIDAH 1993-1994, 164, 209). Secondly, while Buchholz initially assigned to Byblos the Vapheio cup with the number "11/3 N3 XXVII", which he described as the inventory number of the National Museum of Beirut (BuchHolz 1974, 400), it could be inferred from his later references that it came from the Kharji cemetery in Beirut (BucHHOLZ 1999, 392 n. 1470). Though Cadogan included it amongst the "Central Cretan MM IB and MM II pottery....found in the Levant" (CADOGAN 1983, 514), he assigned it in the notes sent to Professor Ward in 1971, to "MM IIB/IIIA (I think)".

Cadogan had no description of the vase in his notes but drew it with a painted spiraliform pattern around the outside. In 1961and 1975 I saw it on display in the National Museum in Beirut. It was wheelmade and had a thin buff fabric and a thin, streaky matt black and dark brown slip with traces of white painted decoration, including a broad line round the inside of the rim and parallel horizontal lines down the back of the handle. Though I was unable to record its provenance, or dimensions, its registration number was clearly visible. Cadogan made it 8.5 $\mathrm{cm}$. in height and $11.8 \mathrm{~cm}$. in rim diameter. Saidah put its height at $7.0 \mathrm{~cm}$. and rim diameter at 10.0 cm. (SAIDAH 1993-1994, 164). It had evidently been mended but was incomplete.

The painted cup without handle No. 4170, found north of the paving in Room XXIII (DUNAND 1939, pl. CLXIV. 4170, 311 f., fig. 251, 311), has been attributed by numerous specialists to MM IB (cf. SCHAEFFER 1948, 66; Hutchinson 1954, 159; Åström 1957, 259; SANDARS 1961, 21; HoOd 1971, 41; LAMBROU-Phillipson 1990, 69). However, Stevenson Smith expressed reservations about this classification (Stevenson Smith 1965, 13 f.), and Cadogan rejects it altogether (WARD 1971, 77 n. 313).

Dunand reported that his excavations at Byblos in 1938 yielded two Kamares type cups with flat handles (DunAnd 1939, 77; WARD 1971, 77). They have never been published.

Dunand dug the Byblos settlement site in rigorously horizontal layers, $20 \mathrm{~cm}$. deep, ignoring the natural stratigraphy, and established no levels of 






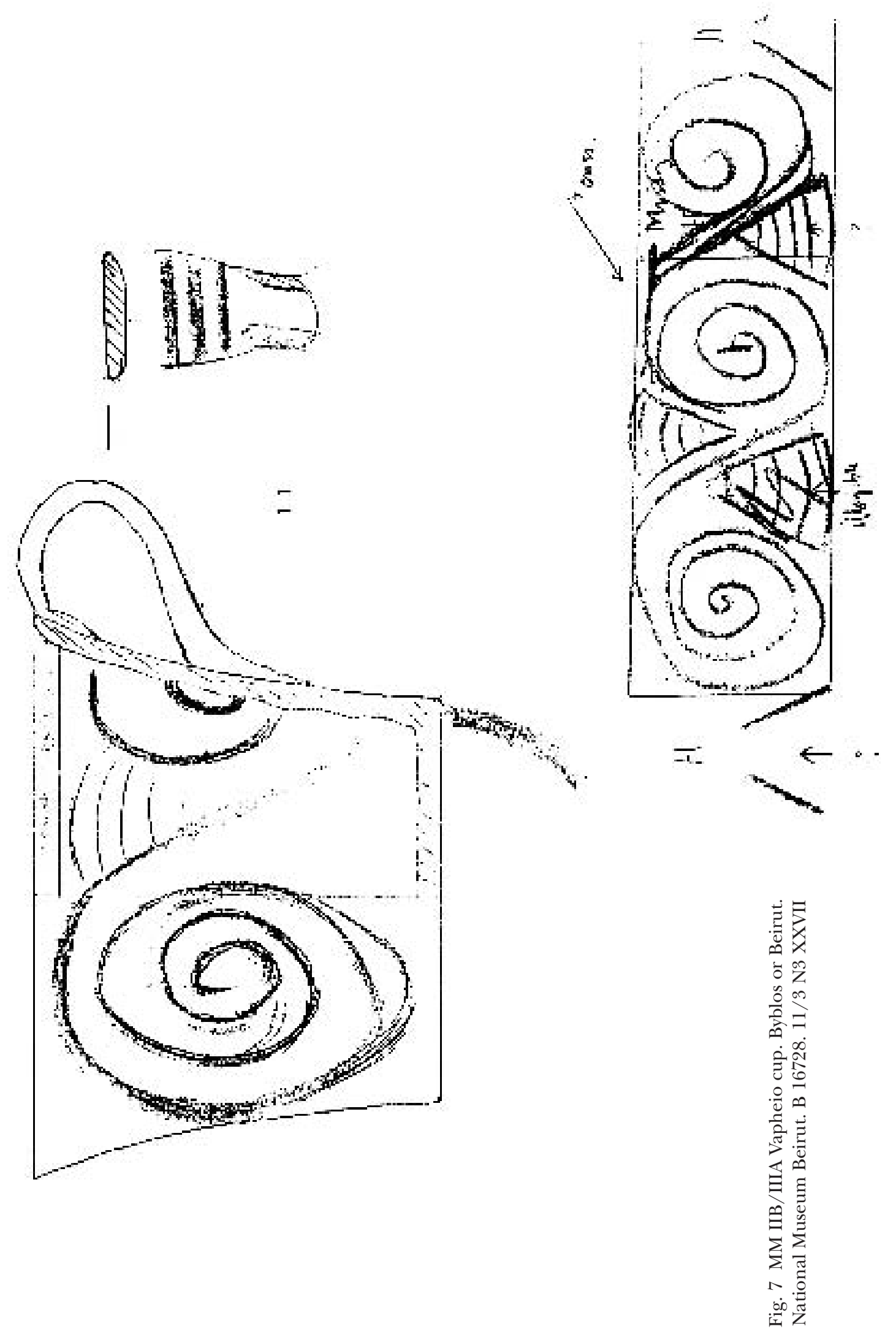
occupation or even a relative chronology (DUNAND 1939, 6 ff.). As Åström has diplomatically observed, Dunand's discoveries at Byblos do not help us with absolute dates (Åström 1957, 259).

The second MM IIA bridge-spouted jar found at Byblos came from a tomb looted in 1955. It is now in the Archaeological Museum of the American University of Beirut (No. 55.121) and has been frequently illustrated and exhibited (BARAMKI 1967, pl. III, 24 f. No. 19 ; А̊̆тrÖм 1967, 125 n. 2; BARAMKI 1973, pl. IV. 1, fig. 4. 2, 30; Liban 1998, 96 Ill., 97; Badisches Landesmuseum Karlsruhe 2000, 317 No. 300, with additional bibliography). MacGillivray has assigned it to MM IIB (MACGILlivRAY 1998, 106). It was "wheel-made of finely levigated red ware ..... black slipped in white with stylised floral designs and a row of red circles" (BARAMKI 1973, 30). Height: $14.4 \mathrm{~cm}$. Diameter: $15.5 \mathrm{~cm}$. The rest of the contents of the tomb recovered by the Archaeological Museum consisted, according to Baramki, of 13 locally made vases of the Early Bronze Age, and six belonging to MB II (BARAMKI 1973, 27). The latter comprise three piriform jugs (Nos. 14, 15, 16), a deep bowl (No. 17) and a large jar (No. 18) (BARAMKI 1973, 30). Seeden has placed these vases in the middle of MB II (WARD 1971, 77 n. 314), which is the horizon to which Baramki has assigned the Kamares bridge-spouted jar (BARAMKI 1973, 30). Given the circumstances in which the discovery was made and the contents of the tomb retrieved, it would be unwise to place too much reliance on this synchronism.

Lambrou-Phillipson's statement that "the earliest Cretan objects imported into the Levant have been found at Byblos: two MM I bridge spouted jars, two cups with strap handles and other sherds, and a MMIB cup" (LAMBrou-PhILLIPSON 1990, 69) would appear to be completely mistaken.

Two MM IIA cups were said to have turned up in the Kharji cemetery in central Beirut, but one of them could have come from Byblos (see above). The only one with a more or less certain provenance is a Kamares egg-shell ware cup with stemmed base and strap handle from Grotte 4 Chambre 1 No. 45 (F620) (CADOGAN 1983, 514 n. 110; WARREN and HANKEY 1989, pl. 12A, 134 f.; SAIDAH 1993-1994, pl. 17.1a-c, pl. 18. 1a-b, 164, 166, 208; HANKEY 1996, 12 Ill., 14). It has been attributed to late MM IIB or early MM IIIA by MacGillivray (MACGILLIVRAY 1998, 105). No technical details have been published or recorded about the piece other than that it had "two $1 \mathrm{~mm}$ vent-holes in base for safe firing" (SAIDAH 1993-1994, 164) and was decorated with faded "polychrome" paint (WARREN and HANKEY 1989, 134;
SAIDAH 1993-1994, 164). Saidah gave the rim height as $15.0 \mathrm{~cm}$. and rim diameter as $23.0 \mathrm{~cm}$. (SAIDAH 1993-1994, 164), whereas Hankey gave its height as $7.5 \mathrm{~cm}$. and rim diameter as $11.8 \mathrm{~cm}$. (HANkeY 1996, 14), half the dimensions published by Saidah. Estimation of its size is further complicated by the scale of the drawing reproduced by Warren and Hankey in 1989 (WARREN and HANKEY 1989, pl. 12A) as the rim height works out at $9.45 \mathrm{~cm}$. and the rim diameter at $14.25 \mathrm{~cm}$. It appears to have been mended from sherds (HANKEY 1996, 14).

Grotte 4 Chambre 1, also referred to as Tomb 1 (HANKey 1996, 12), was discovered in 1954 during construction work in downtown Beirut (SAIDAH 1993-1994, 137). Only the scrappiest details are available about the deposit, which was cleared in a rescue operation by the Lebanese Directorate General of Antiquities. Grotte 4 consisted of a rock cut cave with two chambers, one round (Chamber 1) and the other rectangular (Chamber 2) (SAIDAH 1993-1994, pl. 1, 141). The objects recovered from Chamber 1 were not plotted in situ, and Seeden states that "it is practically impossible to identify the exact provenance of each artefact from these Bronze Age rock tombs in terms of its original findspot and burial context" (SAIDAH 1993-1994, 141). Though Warren and Hankey confidently dated the assemblage of objects from Chambre 1, including the MM IIA cup, to the Egyptian XII ${ }^{\text {th }}$ Dynasty (WARREN and HANKEY 1989, 134 f.), Hankey reversed the order of the chambers in her own, later report (Hankey 1996, 12, 15; SeEden 1996) and was unable to make notes on 24 items said to be from the same deposit which were listed as part of the private collection of the then Prime Minister of the Lebanon (Hankey 1996, 12). As Chambre 1 contained material from both the Middle and Late Bronze Ages, and no record exists of the sequence of burials, it seems rash to draw any conclusions about the chronological horizon to which the MM IIA cup belonged (SAIDAH 1993-1994, 206).

Said to belong to an early stage of MB IIA at Sidon on the Lebanese coast, south of Beirut, is a recently discovered animal bone deposit with pottery. It included an "exceptionally fine polychrome cup with one handle of the so-called Palatial Classical Kamares" attesting to contacts "in the Middle Minoan IIA/B period and the $13^{\text {th }}$ Dynasty in Egypt" (SERhal 2003, 23).

Two fragmentary vases from Hazor Stratum 3 in inland Palestine have often been cited in the literature as possible imports from Crete. They have recently been republished in a comprehensive man- 
ner by Dothan, Zuckerman and Goren, who concluded from the petrographic analysis that only one of them (Reg. Nos. C718/20 and C370/18) had a Minoan origin (DoTHAN et al. 2000, 2, fig. 1, 1 ff.). It consists of two adjoining fragments of a large open vase, with a highly burnished dark grey slip and white painted spiraliform decoration. Walberg, Niemeier and Hood were all consulted on the attribution and dated it to MM IIB or MM IIIA (DoTHAN et al. 2000, $4 \mathrm{n}$. 14). It appears that none of these authorities actually saw the two pieces in question, and Cadogan, who had not examined them either, was uncertain about their foreign derivation (CADOGAN 1983, 514), though inclined to place them in MM II-III (WARD 1971, 78 n. 319). Other experts such as Betancourt, Buchholz, Hankey and Walberg have included these pieces, without qualifications or queries, in their lists of Minoan pottery from the Levant and evidently been prepared to give them the benefit of the doubt as authentic Cretan exports (BETANCOURT 1998, 6; BuCHHOLZ 1999, 392; HANkey 1996, 11; WALberg 1991, 116; cf. Dothan $e t$ al. 2000, 3 n. 13).

Betancourt, however, is now of the opinion that Dothan and her colleagues have not really proven their case that this piece is Minoan, and its full description, including the fact that it is heavily burnished, casts serious doubts on its Cretan origin. It may be, according to him, Minoanising rather than Minoan (personal communication). Cadogan has informed me that he is inclined to share Betancourt's opinion (personal communication). Dothan and her colleagues have concluded that the other sherd from Hazor, a modelled rim (?), is of local Canaanite derivation (Reg. No. C370/17) (DoTHAN et al. 2000, $4 \mathrm{ff}$.). All these fragments occurred in Stratum 3 dated to MB IIC (Dothan et al. 2000, $1 \mathrm{ff}$.) and are, according to the authors, "the only secure evidence of Aegean pottery in Egypt or the Levant during this period" (Dothan et al. 2000, 11). Given the uncertainties involved in the attribution of the so-called Minoan fragments, it would be unwise to rely too heavily on this synchronism.

A sherd attributed to MM IIB by Larry Stager comes from Ashkelon further south on the Palestinian coast (STAGER 2002). It is part of the carinated, out-turned rim of a cup with a dark brown slip and white painted decoration inside and out. It occurred with Egyptian sealings in what has been called the "Moat Deposit" between Gate 1 of Phase 14 and Gate 2 of Phase 13. The Egyptian sealings have been dated to the end of the $12^{\text {th }}$ Dynasty or the beginning of the $13^{\text {th }}$ Dynasty, either side of around 1800
B.C. The local ceramic material has been securely dated by the excavator to MB IIA.

The work done by Kemp and myself on the Minoan pottery from Egypt has not been superseded, despite numerous attempts by scholars to reinterpret the data to suit their own chronological convenience (Kemp and Merrillees 1980). A good example is provided by Warren and Hankey who have difficulty understanding how a detailed analysis of findspots can lead to less rather than more precision in the absolute dates (WARREN and HANKEY 1989, 134 f.). An important neutron activation analysis of the MM IIA and related sherds from Egypt in the British Museum has recently been published and confirmed the attributions made by Kemp and myself to centres of manufacture in Crete and Egypt respectively (FITTON et al. 1998). Some of this material, which came from Kahun and el-Haraga, was included in the exhibitions "Crete - Egypt. Three thousand years of cultural links" held in the Archaeological Museum at Herakleion in 1999-2000 (KARETSOU 2001, 50 f. Nos. 26, 27a-c) and "Im Labyrinth des Minos" held in the Badisches Landesmuseum, Karlsruhe, in 2001 (Badisches Landesmuseum Karlsruhe 2001, 322 Nos. 315, 316). In both cases the imports have been dated without qualification by Lesley Fitton to MM II, c. 1850-1800 B.C. More light has also been shed on the findspots of the vases from Kahun, using Petrie's Journals and Notebooks, but without improving our ability to date the deposits more closely (GALLORINI 1998; FitTON et al. 1998).

The pieces of imported Cretan pottery from the fill in the North Pyramid cemetery (Pyramid of Amenemhat I) at el-Lisht, now in the Metropolitan Museum of Art in New York, were also included in the exhibition on "Crete - Egypt" in the Archaeological Museum at Herakleion in 1999-2000 (KARETSOU 2001, 52f. Nos. 28, 29a-d). They comprise the bridge-spouted vase attributed to MM I by Kemp and myself (Kemp and Merrillees 1980, pl. 1, 1, 3) and by Betancourt to MM IB-IIA (KARETSOU 2001, 55 No. 28), and four sherds, one of them previously unpublished (Karetsou 2001, 52 No. 29a). They have all been classified by Betancourt as MM II and dated to the $19^{\text {th }}-18^{\text {th }}$ centuries B.C. or Middle Kingdom context.

Warren and Cadogan have usefully commented on the classification/relative dating of the material published by Kemp and myself (WARREN 1985; CAdogan 1983, 515) but added nothing new to the data. Warren and Hankey have also re-assigned the Minoan vase from Qubbet el-Hawa to "MM I and 
probably MM IA" (WARREN and HANKEY 1989, 130; cf. MANNING 1995, 108 f.), though MacGillivray would place it in the MM IB to IIA transition (MACGILLIVRAY 1998, 103) and Betancourt in the MM II period proper (BETANCOURT 1985, 90). Cadogan concurs with a later dating (personal communication). Far from restricting the span of the associated Egyptian grave-goods to the early $12^{\text {th }}$ Dynasty, not excluding the First Intermediate Period, as Warren and Hankey have done (WARREN and HANkEY 1989, 130), a professional Egyptologist like Peter Lacovara has argued for a "chronological range even wider than the authors [ Kemp and Merrillees ] suggest for the Kamares vase, invalidating its use to attempt to pin down MM II to Dynasty 12” (Lacovara 1988, 305). Dorothea Arnold is reported to have re-examined the contexts of the MM IIA and Minoanising pottery from el-Haraga and determined that it ranges in date from the mid-12 $2^{\text {th }}$ Dynasty to the beginning of the $13^{\text {th }}$ Dynasty, that is, around $1900 / 1875$ B.C. to 1800/1775 B.C. (Phillips 1991, 22), but the paper in question has not yet been published.

The only significant new finds of which I am aware from the Nile Valley are several Minoan sherds from Tell el-Dabca. About eight fragments from one or more oval mouth amphorae of a light ware with simple dark bands, attributed by Warren to MM IIA, have turned up in Stratum e/3 at cEzbet Rushdi (CZERNY 1998, 46, fig. 21, 46; information from Tine Bagh). Some of these pieces were found below the temple level, that is, before the reign of Senusret III, c. 1875-1850 B.C., while others were contemporary with the temple. Further precision will have to await their full publication but it would seem on this evidence alone that MM IIA coincides with the first half of the $19^{\text {th }}$ century B.C.

While this material does not belong to the usual run of Cretan imports at this time, four sherds of the more conventional Kamares Ware came from Stratum d/1 (= G/4) at Tell el-Dabca which, according to Walberg who first published them, "are likely to belong to the same vessel" evidently a cup (WALBERG 1991, 117 Reg. No. 7255; no Reg. No.; Reg. No. $7255 \mathrm{~B}$; [no indication of an registration number ]). She has assigned the fragmentary vase to "palatial Classical Kamares (MM IIA-IIB-IIIA)” (WALBERG 1991, 117). MacGillivray, however, has taken issue with Walberg's designation and reclassified the vase as a "Rounded Cup of Type 6 in the new typology of Knossian pottery of the Old Palace period" (MACGILlivraY 1995, 81). His presentation of the parallels for the cup from Tell el-Dabca reveals that the "Old Palace Period" ends at the same time as
MM IIB, to which the find from Egypt presumably belongs (MACGILLIVRAY 1998, 105).

The identity, and even the number of pieces of Minoan pottery from Tell el- Dabca, some of which have been exhibited on several occasions (Museen der Stadt Wien 1994, 208 f. No. 234; Badisches Landesmuseum Karlsruhe 2001, 213, fig. 178, 321 No. 311 ), become complicated when account is taken of the results of neutron activation analysis of four pieces of Kamares ware by Patrick E. McGovern (McGovern 2000, 155 PMG108-PMG110). He observes that the provenience of two of the four sherds published by Walberg (Tell el-Dabca Reg. Nos. 7255A-B - Walberg's 7255 is presumably McGovern's 7255A) is uncertain, the composition being "most similar to Athens DFD631, of probable local origin" (McGovern 2000, 155 PMG110). Furthermore Mc Govern examined two other pieces, "a Cup rim, painted, Kamares ware” (Reg. No. 7254K) (McGovern 2000, 155 PMG108) and a "Cup base, white painted and burnished, Kamares ware" (Reg. No. 3336I) (McGovern 2000, 155 PMG109). Neither yielded any positive indications about their sources of production, but the former was found to be "most similar to Vounari (near Phlamoudhi, northeastern Cyprus) ABVN07, of Cypriot origin" and the latter, "most similar to Athens DFD234, of uncertain origin". McGovern considered that the three cups of Kamares ware were all of uncertain provenience because his database lacked any coverage of Crete. He concluded that "the closest samples in mean Euclidean space are from Cyprus and central mainland Greece. Unless the latter samples were themselves imported from Crete, it is likely that chemically similar clays are to be found in Crete and elsewhere in the Aegean and eastern Mediterranean" (McGOVERN 2000, 52).

The four fragments believed to have come from the same cup, which include Reg. Nos. 7255[A] and 7255B and were assigned by Walberg to Stratum d/1 at Tell el-Dabca (WALBERG 1991, 117), were placed by McGovern in Stratum d/1-2 (MCGoverN 2000, 155). Bietak has dated the cup to c. 1780 B.C. (Museen der Stadt Wien 1994, 208 f. No. 234; Badisches Landesmuseum Karlsruhe 2000, 321 No. 311), while he gives Stratum d/1 a range of 1775-1750 B.C. and Stratum d/2 a range of 1825-1775 B.C. (Museen der Stadt Wien 1994, 36). Dever would place Stratum d/1 between 1875 and 1800 B.C. (Dever 1992, 9). The other two so-called Kamares sherds, which have not so far been separately published, have been assigned by McGovern to Strata c? and b/2-3 (McGoverN 2000, 155), which according to Bietak run approxi- 
mately from 1750 to 1650 B.C. (Museen der Stadt Wien 1994, 36), but their evidence must be treated with due caution until their identities and contexts have been confirmed.

In assessing the implications of the MM II pottery finds from the Levant for synchronisms and absolute dates of the Bronze Ages in the Aegean, Cyprus, Syria and Palestine, the accumulation of new data has not gone far in dispelling the imprecision and uncertainties in the stratification and contexts of much of the material surveyed.

If the synchronism between MM I in Crete and MC I in Cyprus is reasonably secure, there is almost no evidence from the rest of the Levant, excluding for the moment Egypt, which enables MM IIA to be reliably correlated with individual phases of the Middle Bronze Age in Cyprus, Syria or Palestine. While nothing indicates that that MM IIA exports occurred earlier than MB IIA, they could have been associated with MB IIB material at Ras Shamra and Byblos. The MM IIA/B cup from Sidon, if authoritatively classified, and the MM IIB sherd from Ashkelon both belong to MB IIA. The Hazor sherds, if really of MM IIB or IIIA, can be dated to MB IIC.

In Egypt there is no reason to modify the view expressed by Kemp and myself in 1980, based on our detailed study of the material and its contexts, that MM IB started after 2000 B.C., a point with which Hankey agreed, and MM II ended around 1775/ 1750 B.C. (KemP and Merrillees 1980, 267), a point with which Stager agrees (STAGER 2002). The evidence from cEzbet Rushdi and el-Haraga seems to indicate that MM IIA overlapped with the $19^{\text {th }}$ century B.C., and the MM IIB vases from Ashkelon Phases 14-13 and Tell el-Dabca Stratum d/1 can be dated to approximately 1800/1775 B.C., which fits in well with the absolute chronology originally proposed by Kemp and myself and the dating independently arrived at by Stager (STAGER 2002).

If MM I continued into the $20^{\text {th }}$ century at least and possibly even into the $19^{\text {th }}$ century B.C., this time frame would overlap with the range of 1950 to 1850 B.C. which I have independently advanced for MC I in Cyprus. The evidence from Egypt, including Tell el-Dabca, would favour a span of the early $19^{\text {th }}$ century B.C. to 1750 B.C. for MM II (cf. MANNING 1995, 217; MANNING 1999, 78). Given the elastic quality of the relative and absolute chronologies of the Middle Bronze Age in Syria/Palestine, the MM II sequence in Crete can be accommodated without serious conflict in any of the dating permutations and combinations devised by the experts for this region (e.g. Dever 1992, 3). There is at least no hint in the archaeological record that MM IIA is earlier than MB IIA, which could begin as early as 2000 B.C. (Dever 1997, 286, fig. 9. 1) and end as late as 1700 B.C. (Bietak 1992, 30, fig. 1; Stager 2002). The implication of these synchronisms is that MB IIA does not overlap with MM I in Crete and MC I in Cyprus. This is not contradicted by the evidence from Cyprus if the two Levantine pithoi from Bellapais Vounous Tombs 64 and 68 are dated not to MB IIA as I and others have done, but to EB IV/MB I, as Kehrberg and Ross have done, evidently more accurately (MANNING 1995, 110; DUNN-VATURI 2003, 182).

The finds of Cypriote White Painted Pendent Line Style Pottery abroad help define the next set of synchronisms (MerrilleEs 2002). This ware does not precede MC III in Cyprus, MB IIA in Syria and Palestine and Stratum F at Tell el-Dabca, dated by Bietak to around 1690 B.C. (BIETAK 1992, 30 Fig. 1) but earlier by Dever (Dever 1997, 295, fig. 9. 4). It must by definition have originated in Cyprus before this date. If, as I have argued, MC III began around 1750 B.C. and MM III began about the same time, as Manning has independently concluded (MANNING 1995, 217; MANNing 1999, 78), then MB IIA must have carried on at least until 1700 B.C., as Bietak and others have proposed (DEver 1992, 3, fig. 1). Otherwise the dates for the Middle Minoan and Middle Cypriote periods would have to be raised even further to accommodate the overlap between MC III in Cyprus and MB IIA in Palestine. In the light of the latest scientifically based evidence for Aegean Late Bronze Age chronology, this may in any case have to happen (MANNING et al. 2002). Be that as it may, I would, in the current state of our knowledge, propose the following absolute chronology for the Middle Minoan period in Crete:

\begin{tabular}{|c|c|}
\hline MM IA & -1975 B.C. \\
\hline MM IB & 1975-1900 B.C. \\
\hline MM IIA & 1900-1825 B.C. \\
\hline MM IIB & $1825-1750 \mathrm{I}$ \\
\hline MM IIIA & $1750-$ \\
\hline
\end{tabular}

Historically what emerges from the data assembled is the fact that nearly all the pieces of Minoan pottery recorded turned up in their proper chronological horizon, that is, they were deposited or discarded within a time frame not too far removed from the dates of their importation and manufacture. From this we can deduce that they were almost certainly not heirlooms or keepsakes, that is, objects which had been in circulation, use or care for an extended period, much as we might decorate our homes to-day with a Chinese vase of the $18^{\text {th }}$ or $19^{\text {th }}$ century A.D. 
This very fact also suggests that the Minoan vases had a utilitarian purpose, as well as novelty value, and were thrown away when broken or buried with the dead.

Despite their very small number in total, the pottery containers from Crete exhibit a standardisation of shapes that hints at some specialisation in their manufacture and/or marketing. The two most common types are the bridge-spouted jar and carinated cup with handle. It has been suggested that these exports included vases which were probably shipped for their contents as a well as small open shapes which must have been traded for their own sake (Betancourt 1998, 5). The Middle Minoan pottery from Egypt has a much wider range of shapes than that in Syria and Palestine, including strainer vases and others with different kinds of spout (CADOGAN $1983,514)$. We are not in a position to assess the commercial significance of these finds, but there may have been a different kind of customer demand in Egypt to the rest of the Levant.

One thing of which we can be quite sure is that the Minoan pottery was not part of the exchange of prestige goods between local rulers or kings. Ceramics were not the stuff of gifts considered appropriate for leaders to present to their counterparts in other places, and the burial deposits in which the vases occurred in Cyprus, Syria, Palestine and Egypt indicate middle class, not royal connections. The material from el-Haraga, Kahun and el-Lisht may even have been associated with the villages of workmen engaged in tomb and pyramid construction during the Middle Kingdom. While Stewart thought that the MM IIA cup from Karmi Palealona on the north coast of Cyprus belonged to a seafarer who picked it up on his travels (STEWART 1963, 204), there is no reason to discount the possibility that it, like the other Minoan vases encountered in the Levant, was simply sold by a merchantman plying the eastern Mediterranean basin.

It goes without saying that all of the Cretan vases must have been transported by ship, and the proximity of the finds to the coast in Cyprus, Syria and Palestine confirms the route taken by the vessels. It can be no coincidence that the earliest Minoan pottery export to the Levant has turned up on the northern coast of Cyprus, which is the closest landfall to Crete and on the northerly sea lane from west to east around the east Mediterranean. Speculating on the nationality of the merchantmen which might have been engaged in this traffic is, however, an exercise in historical futility, as no records exist of maritime ventures in the region at this time, no wreck has been found belonging to this period, and the finds are too few to discern a pattern in their occurrence overseas. It is nevertheless hard to believe that the Minoans themselves were not in some way involved in the trade, and circumstantial evidence exists for their seafaring in the Middle Bronze Age.

There are, however, no texts, frescoes or other graphic representations from Middle Kingdom Egypt which can be specifically linked to Crete or the rest of the Aegean world. This absence of documentation about the source of the Minoan pottery from the Nile valley is in stark contrast to the situation in the New Kingdom when all categories of evidence are attested and indicate a level of contact and degree of knowledge which go well beyond previous experience. The only conclusion one can come to about the presence of Middle Minoan pottery in the Levant is that it reached its destinations through sporadic, low level, probably mercantile shipping ventures which were undertaken for profit more than prestige and initiated a relationship which expanded in the early $18^{\text {th }}$ Dynasty before the Mycenaeans supplanted the Minoans in Crete and the rest of the Aegean (cf. FiтTON et al. 1998, $131 \mathrm{ff}$. ).

\section{Acknowledgements}

I am beholden to a number of archaeologists for the assistance they have given this project. Firstly it was Professor Bietak who asked me to undertake a study of where Kamares Ware first appears in the eastern Mediterranean as part of his project on the "Synchronization of Civilizations in the Eastern Mediterranean in the $2^{\text {nd }}$ Millennium B.C." I am most grateful to him for his invitation, support and encouragement. As Minoan pottery is not my archaeological speciality, it was agreed with Professor Bietak that I would avail myself of the services of an authority on Cretan ceramics, and Professor Philip Betancourt kindly consented to be my advisor. His help has been much appreciated. Fortunately for me a number of other scholars have reviewed the evidence relevant to this study and published their considered views not only on the ceramic classifications but on the relative and absolute chronology. Foremost amongst them have been Gerald Cadogan, Peter Warren and Vronwy Hankey, whose works have been frequently quoted. I have, of course, also consulted other syntheses on the subject, especially those by Betancourt and MacGillivray. Cadogan has also been good enough to answer all my queries and comment on this paper in draft. I thank him most cordially. 
Of particular value to this study has been Cadogan's paper on "Early Minoan and Middle Minoan Chronology” delivered to Professor Porada's Seminar on the Archaeology of Eastern Europe, the Eastern Mediterranean and the Near East, at Columbia University in February 1982. It was published in "Chronologies in Old World Archaeology, 1981-1982" in the American Journal of Archaeology Vol. 87, 1983, 507-518. It is thanks to Dr Allan Gilbert, one of Porada's students, that I was able to deliver my own paper to the Columbia University Seminar on the Ancient Near East in New York on 25 November 2002. In addition Cadogan generously lent me all his notes on the material which he saw on a visit to the National Museum of Beirut in 1966 and on the rest of the Middle Minoan finds from the Levant. These included a long letter which he sent to the late Professor William Ward in 1971. It commented in detail on a draft of Ward's book on Egypt and the East Mediterranean World 2200-1900 B.C., which was published in Beirut the

\section{Bibliography}

ĂsTRÖM, P.

1957 The Middle Cypriote Bronze Age. Lund.

1962 Remarks on Middle Minoan Chronology, Kretika Chronika, 144-148.

1967 New Evidence for Middle Minoan Chronology, in: Proceedings of the Second International Cretological Congress (Athens), 120-127.

1979 The Find Contexts of Some Minoan Objects in Cyprus, in: Acts of the International Archaeological Symposium "The Relations between Cyprus and Crete, ca. 2000-500 B.C." Nicosia $16^{\text {th }}$ April-22 $2^{\text {nd }}$ April $1978,56-62$

Badisches Landesmuseum Karlsruhe

2000 Im Labyrinth des Minos. Kreta- die erste europäische Hochkultur, Munich.

BARAMKI, D.

1967 The Archaeological Museum of The American University of Beirut, Beirut.

1973 A Tomb of the Early and Middle Bronze Age at Byblos, Bulletin du Musée de Beyrouth 24, 27-30.

BETANCOURT, P.

1985 The History of Minoan Pottery, Princeton.

1998 Middle Minoan Objects in the Middle East, in: E.H. Cline and D. HARris-CuIne (eds.), The Aegean and the Orient in the Second Millennium (Liège), 5-11. same year. There are many references in Ward's study to Cadogan's views, and I have drawn freely on both sources for my own investigation. I am alone responsible for the results of the present enquiry.

Dr Sophocles Hadjisavvas, Director of the Department of Antiquities of Cyprus, gave me permission to re-examine the two Middle Minoan vases from Cyprus, now in the Cyprus Museum, Madame Annie Caubet, Conservateur-Général of the Département des Antiquités Orientales of the Louvre, let me see the Cretan material from Ras Shamra and kindly provided me with slides, and Dr Roger Moorey arranged for me to study the Middle Minoan sherd from Ras Shamra in the Ashmolean Museum, Oxford, and for a photograph to be supplied of the piece. Information about the Middle Minoan sherds from Ashkelon, and slides, were generously supplied by Professor Larry Stager, and from 'Ezbet Rushdi, by Dr Tine Bagh. To them all I express my warmest gratitude.

BIETAK, M.

1992 Die Chronologie Ägyptens und der Beginn der Mittleren Bronzezeit-Kultur, ÄEL 3, 29-37.

BuchHolz, H.-G

1974 Ägäische Funde und Kultureinflüsse in den Randgebieten des Mittelmeeres, AAnz 3, 325-462.

1999 Ugarit, Zypern und Ägäis, Münster.

BuchHolz, H.-G. and KarageOrghis, V.

1973 Prehistoric Greece and Cyprus, London.

Cadogan, G.

1983 Early Minoan and Middle Minoan Chronology, AJA 87, 507-518.

Caubet, A. and MatoÏan, V.

1995 Ougarit et l'Égée, in M. Yon, M. SzNYCER and P. BORdreuil, Le Pays d'Ougarit. Autour de 1200 av. J.-C. Histoire et archéologie, Paris, 102-112.

CoHEN, S.L

2002 Canaanites, Chronology, and Connections: the Relationship of Middle Bronze Age IIA Canaan to Middle Kingdom Egypt, Winona Lake.

Courtols, J.

1979 Ras Shamra (Ugarit ou Ougarit), in: Supplément au Dictionnaire de la Bible Tome 9, Fascs. 52-53, Paris, cols. 1124-1295. 
CZERNY, E.

1998 Zur Keramik von 'Ezbet Rushdi (Stand Mai 1997), Ä $\mathcal{E}^{2}$ 8, 41-46.

DEVER, W.G.

1992 The Chronology of Syria-Palestine in the Second Millennium B.C., Ä ẼL 8, 39-51.

1997 Settlement Patterns and Chronology of Palestine in the Middle Bronze Age, in: E.D. Oren (ed.), The Hyksos: New Historical and Archaeological Perspectives, Philadelphia, 285-301.

Dothan et al. 2000 = Dothan, T., ZuCKerman, S., and GOREN, Y.

2000 Kamares Ware at Hazor, IEJ 50, 1-15.

DUNAND, M.

1939 Fouilles de Byblos. Tome 1er. 1926-1932, Paris.

Dunn-VATuri, A.-E.

2003 Vounous. C.F.A. Schaeffer's excavations in 1933. Tombs 49-79, Jonsered.

FitTon et al. 1998 = L. Fitton, M. Hughes and S. QuiRke

1998 Northerners at Lahun. Neutron Activation Analysis of Minoan and related pottery in the British Museum, in: S. Quirke (ed.), Lahun Studies, Reigate, 112-140.

GALLORINI, C.

1998 A reconstruction of Petrie's excavations at the Middle Kingdom settlement of Kahun, in: S. QUIRKE (ed.), Lahun Studies, Reigate, 42-59.

GRACE, V.

1940 A Cypriote Tomb and Minoan Evidence for its Date, AJA 64, 10-52.

HANKeY, V.

1996 A Middle Minoan Cup from the Kharji Cemetery, Beirut, National Museum News No. 3, 10-16.

Hood, S.

1971 The Minoans. Crete in the Bronze Age, London.

HuTCHINSON, R.W.

1954 Minoan Chronology Reviewed, Antiquity 28, $155-164$.

KARETSOU, A. (ed.)

2001 Crete-Egypt. Three thousand years of cultural links, Herakleion.

Kemp, B.J. and MerriLleEs, R.S.

1980 Minoan Pottery in Second Millennium Egypt, Mainz am Rhein.

KuschKe, A.

1962 Bericht über eine Sondage im Palastgarten von Ugarit-Ras Shamra, in: SCHAEFFER 1962, 251-327.

LACOVARA, P.

1988 Review of B.J. Kemp and R.S. Merrillees, Minoan Pottery in Second Millennium Egypt, JNES 47, 304-307.

LAMBrou-Phillipson, C.

1990 Hellenorientalia. The Near Eastern presence in the Bronze
Age Aegean ca. 3000-1100 B.C. Interconnections based on the material record and the written evidence, plus Orientalia: a catalogue of Egyptian, Mesopotamian, Mittanian, Syro-Palestinian, Cypriot and Asia Minor objects from the Bronze Age Aegean, SIMA-PB 95, Göteborg.

Liban 1998 Liban. L'autre rive. Exposition présentée à l'Institut du monde arabe du 27 octobre au 2 mai 1999. Paris.

MacGiLlivraY, J.A.

1995 A Minoan Cup at Tell el-Dabca, $\ddot{A} \mathcal{E}^{2} L$ 5, 81-84.

1998 Knossos. Pottery Groups of the Old Palace Period, London.

McGovern, P.E.

2000 The Foreign Relations of the "Hyksos", Oxford.

MANNING, S.W.

1995 The Absolute Chronology of the Aegean Early Bronze Age. Archaeology, Radiocarbon and History, Sheffield.

1999 A Test of Time. Oxford.

Manning et al. 2002 = S.W. Manning, C. B. Ramsey, C. Doumas, T. Marketou, G. Cadogan and C. L. Pearson

2002 New evidence for an early date for the Aegean Late Bronze Age and Thera eruption, Antiquity 76, 733-744.

MERRILLEES, R.S

1979 Cyprus, the Cyclades and Crete in the Early to Middle Bronze Ages, in: Acts of the International Archaeological Symposium "The Relations between Cyprus and Crete, ca. 2000-500 B.C." Nicosia 16 $16^{\text {th }}$ April-22nd April 1978, 8-55.

2002 The Relative and Absolute Chronology of the Cypriote White Painted Pendent Line Style, BASOR 326, 1-9.

Du Mesnil du Buisson, Comte

1926 Les ruines d'el-Mishrifé au nord-est de Homs (Émèse), Syria 7, 289-325.

Museen der Stadt Wien

1994 Pharaonen und Fremde Dynastien im Dunkel, Vienna.

Pendlebury, J.D.S.

1939 The Archaeology of Crete. An Introduction, London.

Phillips, J.S.

1991 The Impact and Implications of the Egyptian and 'Egyptianising' Material Found in Bronze Age Crete ca. 3000 ca. 1100 B.C., Toronto.

SAIDAH, R.

1993-1994 Beirut in the Bronze Age: The Kharji Tombs, Berytus 41, 137-207.

SALTZ, D.L.

1977 The Chronology of the Middle Cypriote Period, RDAC, 51-69.

SANDARS, N.K.

1961 The First Aegean Swords and their Ancestry, AJA $65,17-29$.

\section{SCHAEFFER, C.F.A}

1931 Les fouilles de Minet-el-Beida et de Ras-Shamra. 
Deuxième campagne (printemps 1930). Rapport sommaire, Syria 12, 1-14.

1932 Les fouilles de Minet-el-Beida et de Ras-Shamra. Troisième campagne (printemps 1931). Rapport sommaire, Syria 13, 1-27.

1936 Missions en Chypre 1932-1935. Paris.

1937 Les fouilles de Ras Shamra-Ugarit. Huitième campagne (printemps 1936). Rapport sommaire, Syria 18, 125-154.

1938 Les fouilles de Ras Shamra-Ugarit. Neuvième campagne (printemps 1937). Rapport sommaire, Syria 19, 193-185.

1939 Ugaritica I, Paris.

1939a Les fouilles de Ras Shamra-Ugarit. Dixième et onzième campagnes (automne et hiver 1938-39). Rapport sommaire, Syria 20, 277-292.

1939b The Cuneiform Texts of Ras Shamra-Ugarit, London.

1948 Stratigraphie Comparée et Chronologie de l'Asie Occidentale (III e et II ${ }^{e}$ millénaires), Oxford.

1949 Ugaritica II, Paris.

1962 Ugaritica IV, Paris.

1978 Ugaritica VII, Paris.

SEEDEN, H.

1996 NM News 3 (1996): 10-16 Errata. Difficulties in the correct numbering of the Kharji tombs, National Museum News 4, 38.

SERHAL, C.D.

2003 Excavations in Ancient Sidon, CBRL. Newsletter of the Council for British Research in the Levant, 23-24.
STAGer, L.E.

2002 The MB IIA Ceramic Sequence at Tel Ashkelon and Its Implications for the 'Port Power' Model of Trade, 353-362, in: M. BieTAK (ed.), The Middle Bronze Age in the Levant, CChEM 3, Wien.

Stevenson SMith, W.

1965 Interconnections in the Ancient Near East, New Haven. STEWART, J.R.

1963 The Tomb of the Seafarer at Karmi in Cyprus, OpAth 4, 197-204.

VALlois, H.V. and FEREMBACH, D.

1962 Les restes humains de Ras Shamra et de Minet el Beida: étude anthropologique, in: SCHAEFFER 1962, 565-630.

WALBERG, G.

1991 The Finds at Tell el-Dabca and Middle Minoan Chronology, $\ddot{A} \mathcal{E} L$ 2, 115-118.

1998 The Date and Origin of the Kamares Cup from Tell el-Dabca, ÄEL 3, 107-108.

WARD, W.A.

1971 Egypt and the East Mediterranean World 2200-1900 B.C., Beirut.

WARREN, P.

1985 Minoan Pottery from Egyptian Sites, The Classical Review 35, 147-151.

WARREN, P. and Hankey, V.

1989 Aegean Bronze Age Chronology, Bristol. 